Araştırma Makalesi / Research Article

DOI: http://dx.doi.org/10.29064/ijma.944589

\title{
Evaluation of Marketing Components of Organic Cosmetics in terms of Sociodemographic Composition of Women Consumers \\ Ayşe Ersoy Yıldırım ${ }^{1}$
}

Asst. Prof., Malatya Turgut Özal University, Faculty of Social Sciences and Humanities, International Business Management Department, Malatya, Turkey / ayse.yildirim@ozal.edu.tr.

\begin{abstract}
The study aims to examine the evaluations of female consumers in terms of the socio-demographic variables for the marketing components of organic cosmetics. The study is designed as quantitative research in the descriptive model. The main population of the study is the female consumers in Malatya province. 583 samples with population characteristics were found suitable for the research. The consumer evaluation survey for the marketing components of organic cosmetic products and the survey form containing the questions concerning the socio-demographic qualities of the consumers were used as the assessment instrument. The unpaired t-test and one-way analysis of variance were used in the data analysis. Significant differences were found between the socio-demographic qualities of the participants and their evaluations for the marketing components of organic cosmetics.
\end{abstract}

Keywords: Marketing, Marketing Components, Organic Cosmetics, Consumer Evaluation, Socio-Demographic Qualities.

JEL Classification: M30, M31, M39

ORCID $^{1}$ : 0000-0002-6895-309X

Received Date: 29.05 .2021

Accepted Date: 19.08.2021

How to Cite this Article: Yıldırım, A. E. (2021). Evaluation of Marketing Components of Organic Cosmetics in terms of Sociodemographic Composition of Women Consumers. International Journal of Management and Administration, 5(10), 71-90.

\section{Organik Kozmetiklerin Pazarlama Bileşenlerinin Kadın Tüketicilerin Sosyo-Demografik Kompozisyonu Açısından Değerlendirilmesi}

\section{Ayşe Ersoy Yıldırım}

Dr. Öğr. Üyesi, Malatya Turgut Özal Üniversitesi, Sosyal ve Beşeri Bilimler Fakültesi, Uluslararası İşletme Yönetimi Bölümü, Malatya, Türkiye / ayse.yildirim@ozal.edu.tr.

Özet: Bu çalışmanın amacı, organik kozmetiklerin pazarlama bileşenlerine yönelik, kadın tüketicilerin değerlendirmelerini sosyodemografik değişkenler açısından incelemektir. Çalışma tanımlayıcı modelde nicel araştırma olarak tasarlanmıştır. Araştırmanın ana kütlesini Malatya ilindeki kadın tüketiciler oluşturmaktadır. Evrenin özelliklerini taşıyan 583 örneklem, bu çalışma için uygun bulunmuştur. Ölçme aracı olarak organik kozmetik ürünlerin pazarlama bileşenlerine yönelik tüketici değerlendirme anketi ve tüketicilerin sosyo-demografik niteliklerine yönelik soruları içeren anket formu kullanılmıştır. Veri çözümlemede bağımsız örneklem $\mathrm{t}$ testi, tek yönlü varyans analizinden faydalanılmıştır. Katılımcıların sosyo-demografik özellikleri ile organik kozmetiklerin pazarlama bileşenlerine yönelik değerlendirmeleri arasında anlamlı farklılıklara rastlanmıştır.

Anahtar Kelimeler: Pazarlama, Pazarlama Bileşenleri, Organik Kozmetik, Tüketici Değerlendirmesi, Sosyo-Demografik Nitelikler. JEL Sinıflandırması: M30, M31, M39

ORCID ${ }^{1}$ : 0000-0002-6895-309X

Başvuru Tarihi: 29.05.2021

Kabul Tarihi: 19.08.2021

Bu Makaleye Atıf İçin: Yıldırım, A. E. (2021). Evaluation of Marketing Components of Organic Cosmetics in terms of Sociodemographic Composition of Women Consumers. International Journal of Management and Administration, 5(10), 71-90. 


\section{INTRODUCTION}

Cosmetics have a significant portion in the daily care habits of people unnoticeably. An average person uses at least several cosmetic products together every day. The whole of suncream, hair care products, shaving materials, including personal hygiene products such as skin cream, make-up materials, deodorant, perfume, soap, shampoo, mouth, and tooth-care products, are defined under cosmetics (ISO, 2011: 9). The majority of people think that they have very few problems arising from such products. However, the experts state that long-term use may cause many external and internal diseases to emerge instantly or in years. It was shown in clinical trials that they may cause physical impacts such as distraction, depression, and physical adverse effects such as genital organ problems, hypertension, cardiac rhythm disorders. As shown by the result of the clinical research conducted in Sweden in 2002 according to Salter (2005), it is still a matter of research that Triclosan that is used in toothpaste, soaps, body and vaginal shampoos, domestic cleaning products are contained in high concentration in $60 \%$ of the breast milk samples, creams included dense chemicals such as silicon-based dimethicone leading to a velvet softness on the skin and petrolatum, a gelatine-like chemical agent made of petrol, and another agent, Phthalate caused congenital disabilities in babies and testicle disorders in men and triggering of some cancer types. Organic cosmetics recommend people the opportunity to meet their needs healthily at that exact point. The products with an organic certificate, every stage of which is certified from the production to the consumption, controlled by the third parties except for the company and the producers, for which no synthetic-based input is used in any of its stages are accepted as organic cosmetics. Organic product consumption in the world has continued to grow in a consolidated trend in every country by the consumers preferring to live a healthy life and consume healthy products. The United States of America with a volume of 40 billion Euros, Germany with a volume of 10 billion Euros, France with a volume of 10 billion Euros, China with a volume of 7.6 billion Euros and Italy with a volume of 3.1 billion Euros attract attention in the world's organic market with a volume of approximately 90 billion Euros (FIBL and IFOAM, 2019). The world's cosmetic market size doubled in eight years and reached 500 billion dollars from 250 billion dollars (Özden et al., 2019: 793). The cosmetic spending per capita in Europe has been detected as 150 dollars, and it has been detected in Turkey as approximately 30 dollars (Çomoğlu, 2012; 2-3). It was detected that the average annual spending was approximate 170.3 dollars per consumer unit in 2016, and it was approximately 189.9 dollars in 2018 in the USA, which is known as the most precious beauty and self-care market in the world (Shahbandeh, 2020: 4). It was detected that organic skincare products constituted $33.5 \%$ and hair care products constituted $33 \%$ of the cosmetic industry in the distribution showing the market share of organic self-care industry based on the product in 2019, According to the same research. It was found that $32 \%$ of the consumers volunteered to purchase organic personal care products (Sabanoğlu, 2020: 9). According to the global market research of 2017, it was detected that $40 \%$ of American consumers preferred to purchase organic make-up products (Kunst, 2019: 20). The global market value of organic cosmetic products in 2018 was approximately 34.5 billion dollars, and this figure is expected to reach approximately 54.5 billion dollars in 2027 (Shahbandeh, 2020: 12). This data is proof of the increasing importance of organic cosmetic market. An indicator of the consumers looking on the bright side of organic products compared to the classical products is the significant increase in organic products' consumption levels in all countries (Nguyen et al., 2019: 205). Therefore some of the studies in the literature focus on the requests of the consumers, the frequency and the place where the consumers purchase organic products (Niessen and Hamm, 2008), the consumers purchasing 
organic products, the reasons behind their preference of organic products (Thompson, 1998: Chninici, 2002; Hughner et al., 2007; Essoussi and Zahaf, 2008; Sarıaya, 2007) and the motives forming the basis of the preference of the consumers on purchasing organic products (Zanoli and Naspetti, 2002; Pearson et al., 2007). It is a non-negligible fact that studies focusing on organic products are frequently conducted on organic food, and cosmetics are at least an important need for consumers. This study is aimed to understand the place of the marketing components of organic cosmetics in the minds of the consumers. Accordingly, the evaluation of the female consumers for the marketing components of organic cosmetics was examined within the framework of this study. This study is considered to contribute to the marketing literature in terms of approaching the viewpoint of the consumers to organics concerning the marketing components.

\section{CONCEPTUAL FRAMEWORK}

There are two fundamental problems of marketing management. One of them is the determination of the market or the markets to be active, which is called the determination of the target market. The second one includes developing and applying the marketing components that are the most suitable for the target markets. The markets are divided into sections according to the consumers, needs, and requests or the purchasing behaviours such as age, sex, income, education, geographic region, size, type. It is often divided into sections according to "general variables" and "situational variables." The general variables are the variables serving to group the consumers in a broad sense, such as demographic, characteristic features, or lifestyle. The situational variables are the consumption volume, purchasing frequency, brand loyalty, and the advantages expected to be gained from the property or brand perceptions (İslamoğlu, 199: 185). The organic cosmetics market has transformed into a new industry based on the increase in demand and the number of producers through these variables. Estimating the expectation of the consumer group forming the focal point of the organic product market and meeting this expectation is based on the marketing components (Zanoli and Naspetti, 2002: 645).

The products with organic certificates, every stage of the production to the consumption, controlled bare y the third parties except for the company, and the producers are named as organic $\mathrm{p}$ According to EU legislation. Cosmetic products are defined as "any substance or preparation intended to be placed in contact with the various external parts of the human body or with the teeth and the mucous membranes for cleaning them, perfuming them, changing their appearance and/or correcting body odors and/or protecting them or keeping them in good condition" (ISO, 2011: 9). For defining the final products as organic, the product with entirely organic substances is called "a $100 \%$ organic product", the product with at least $95 \%$ organic substances is called "an organic product," the product with at least $70 \%$ organic substances is called "a product made of organic substances" (K1lıç et al., 2014: 43-44). Accordingly, if sun creams, hair care products, shaving materials, including personal hygiene products such as skin cream, make-up materials, deodorant, perfume, soap, shampoo, mouth, and tooth-care products are within the scope of organic products, they can be defined under the title of organic cosmetics.

The price is the equivalent of the advantages provided by the other market combination elements. While the product, market uptake, and distribution are cost elements, the price is the only marketing component yielding money (Monroe, 1990:9, Tek, 1999:448). Price is the total value that the consumers accept to pay for the advantages of owning or using a property or a service (Kotler and Armstrong, 2008: 284; Süer, 2014: 261). It is frequently stated in the literature that as the production costs of organic products are high, their prices are high. As the production process 
is under continuous control and storage, protection, and distribution lead to high costs, organic certification systems lay an extra cost to organic cosmetics. It was determined that although various studies show that the price is a deterrent for organic brands, the consumers may be willing to pay the price when they see the high price as a signal for quality (Wier and Calverley 2002: 167). Johri and Sahasakmontri (1998) detected that the consumers who are aware of the value of the health of human beings, with a high knowledge level, are ready to pay more for purchasing both hygiene-related personal care products and cosmetic products as make-up materials produced from organic components.

Packaging is a coating, wrapping, covering, or combining the product with a material protecting the content of the product, preventing the deterioration of the product during the transportation, storage, and sales, and easing the use of the product (İslamoğlu, 1999: 345). A measure protecting the quality of organic products by processing and manufacturing the packages of organic products by obtaining the same from organic materials and specifically produced organic coating agents that are suitable. Organic cosmetic products are packaged by bearing logos identifying that the product is an organic product and labels providing organic product assurance. Categorizing organic products in a controlled and consistent manner has been determined to help to create a reputation for ecofriendly products and building trust (Scott and Vigar-Ellis, 2014: 642). Ecocert, USDA, ICEA, Soil Society, BDiH, CosmeBio, and Control Union are pioneering organic certification bodies in the global market. Eco-labels accompany the product certificate state the quality, origin, the producer company, the mode of use, the conditions of use, the content, the storage conditions, the expiry date etc., on the packaging of organic products (Cengiz, 2011:1). Another function of the package is its contribution to the sale of the product. Consumers turn to products that they do not need due to their packages attracting their attention, and this attitude results in purchase for most of the time (Arslan, 2004: 185).

Advertisement; customer marketing as sales promotion and sales point; public relations comprising various programs for company officers or external customers, other companies, the state or the media for supporting or protecting individual product communication (Kotler and Keller, 2012: 40-41); the individual sale which is dominant for the marketing communication mixture of many institutions upon starting the business by selling to the relatively tiny number of customers, which are accepted as the most apparent manifestation of the promotion effort, are considered as promotion techniques. Furthermore, there is the sponsorship comprising a contract to provide financial or intellectual support to an institution or an individual against an activity or the rights to use of its logo in connection to an activity; social media such as internet, e-mail, Facebook, Twitter, Instagram and mobile technologies such as mobile phones and laptops and digital media elements. Consumers usually encounter promotion messages from plural resources. Consumers rely on the resources they perceive as trustworthy. They also focus on providing a correct and consistent message concerning the advantages of consuming organic cosmetics besides managing a set of perceptions by significantly impacting consumers' promotion techniques.

\section{MATERIAL AND METHOD}

\subsection{Research Purpose and Model}

The study aims to examine the point views of female consumers in terms of the socio-demographic variables for the marketing components of organic cosmetics. The study is research in the descriptive model. It is designed for detecting the difference between the socio-demographic features of the female consumers and their evaluations for 
the marketing components of organic cosmetics. The study model was formed by being inspired by the study of Lea and Worsley (2005).

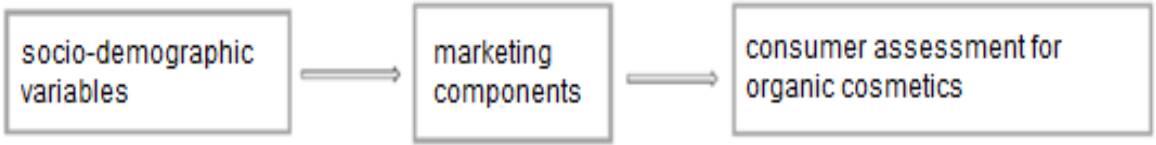

Figure 1. The Study Model

Accordingly, the evaluations by the female consumers for the marketing components of organic cosmetics refer to dependent variables; the socio-demographic variables used in the study (age, marital status, level of education, occupation, income, knowledge status, the status of consumption, economic status, suggesting to other people, purchasing reason) and marketing components (product, price, packaging, promotions) refer to independent variables. The result that is expected from the study is that the evaluations of the female consumers concerning the marketing components of organic cosmetics vary based on socio-demographic variables.

\subsection{Research Population and Sampling Method}

The main population of the study is the female consumers in Malatya province. In order to detect the sampling size, $\mathrm{N}$ : Number of population units, $\mathrm{n}$ : Sampling size, $\mathrm{P}$ : observation rate of $\mathrm{X}$ in the population, $\mathrm{Q}(1-\mathrm{P})$ : Rate of the nonobservation rate of $\mathrm{X}, \mathrm{Z} \alpha(1.96,2.58$ and 3.28 for $\alpha=0.05,0.01,0.001)$ values, $\mathrm{d}=$ Sample fault, $\sigma=$ Population standard deviation, $\mathrm{t} \alpha, \mathrm{sd}=\mathrm{t}$ distribution critical value with the degree of freedom, critical values of the degree of freedom: $s d=n-1$ (Özdamar, 2003: 116-118). According to the calculations made, a minimum of 384 samples are sufficient to represent the population, although the population variant was unknown. 583 samples with population characteristics were suitable for the research. A simple random sampling method was used in the study.

\subsection{Data Collection Tool and Data Evaluation}

The survey was done by face-to-face interview with the female consumers, and the research data in the province of Malatya, Merkez district were collected between September 1 - November 30, 2019. The survey form is formed of two sections. 10 questions in the first section are related to the socio-demographic features of the participants. 37 questions in the second section of the research are for determining the participants' evaluations for the marketing components of organic cosmetics. The scale developed by Yildirım (2020) was used as the data collection tool in the second section of the study. The participants were asked to state their evaluations according to the options which they deem suitable. The Likert Scale scaled the statements helpful for those evaluations as 1- Strongly Disagree, 2 Disagree, 3- Neutral, 4- Agree, 5 - Strongly Agree. The data obtained in the research were analyzed by using the statistics suit software. The level of significance was determined as $(\mathrm{p}=0.05)$ in the data analysis process. Parametric techniques (unpaired t-test, one-way analysis of variance) were used in the research.

\subsection{Literature Search and Developing Research Assumptions}

Studies were conducted for understanding the attitude of consumers towards purchasing organic cosmetic products (Prothero and McDonagh, 1992; Kim and Chung, 2011; Ahmad and Juhdi, 2010; Satos et al. 2105; Ghazali et al. 2017; Lin et al., 2017, Nguyen et al. 2019; Özden et al. 2019). Prothero and McDonagh (1992) examined the impact of ecologically accepted cosmetic products on the industry and tried to exhibit the relationship between environmentalism and the consumption of organic cosmetic products. Prothero and McDonagh (1992) emphasized that organic product manufacturers should focus on ecological problems to sell their products. Kim and Chung (2011) 
examined the intention of the consumers in purchasing organic personal care products. Ghazali et al. (2017) researched organic personal care products on the axis of health and consumer values in repurchasing. It was recommended that the perceived product value be occasionally examined to form customer loyalty and gain new customers with health awareness. Lin et al. (2017) evaluated the correlation between the perceived organic product value and the elements used to form brand loyalty. Nguyen et al. (2019) exhibited the primary determiners of the repetitive intention for purchasing organic cosmetics. Nguyen et al. (2019) determined that some factors such as the belief in the promotion messages, the brand image, the usage experience, sales representative, and social effects impact the intention to purchase organic cosmetics. Özden et al. (2019) tried to examine the consumption of cosmetic products within the frame of health awareness. As a principle, many similarities between the user preferences on organic food and organic cosmetics are stated in the study of Lin et al. (2017). Therefore, some findings obtained from the prior studies on the produced organic food formed the basis of this study. Zanoli and Naspetti (2002) determined that estimating the consumer group's expectation and meeting this expectation depended on the effect of the marketing elements on the consumers. Keller (1993) detected that the components necessary to serve the function of a product, including the price, the product appearance, the packaging, and the usage information, are the most critical factors in increasing the purchases and consumption of cosmetics. It was determined in the study of Yildirım (2020) that price is one of the main factors restricting the purchase and consumption of organic products and affecting the preference of consumers. It was determined by Bozga (2015) that some organic product categories were prone to price, although the high price of organic products is an essential subject for all of the participants. Batte et al. (2003) used the effect of packaging and labels in the decision of the consumers to purchase organic products. It is detected that the packaging and labels are effective in conveying messages and created that image that those products are safer and healthier for the consumers. The industry must convey open and actual information concerning the advantages of organic products, guarantee the reality of organic product demands concerning health and safety, and meet the needs (Ghazali, 2017:161). It was presented in the studies of Onurlubaş and Öztürk (2015) that the advertisement is the most important method for promoting organic products and the sale development, public relations, individual sales are among other essential promotion methods following advertisement as organic products attract the attention of a limited number of people rather than a big community. Ghazali (2017) pointed out the necessity to examine the marketing elements and emphasize the activities to raise the product's perceived value and the consumer's product knowledge to create a positive attitude in the consumers of organic cosmetics. The market research on organic products, the price, packaging, and promotion of organic products are carried out to determine consumer preferences and reveal the consumers' opinions on organic products. It is aimed to determine the evaluations of the female consumers on the marketing components of organic cosmetics in this study. Therefore, the hypotheses were planned to enable the understanding of the evaluations of the female consumers on the cosmetic products. Accordingly, the study's primary hypothesis is to determine whether the socio-demographic data of the consumers led to a statistical difference in their evaluations of the marketing components of organic cosmetics.

$H_{1}$ : There is a significant difference between the socio-demographic qualities of the participants and their evaluations for the marketing components of organic cosmetics. 
Özgen and Yeşiloğlu (2015) examined the differences arising from the demographic variables or lifestyles in purchasing organic products. It was observed that there was a difference between the level of income or age variable and the purchasing attitude of organic food consumers. However, the age or lifestyle variables did not cause a significant difference in the purchasing attitude. Çelik (2013) discussed the demographic characteristics of the consumers purchasing organic food and products and their purchasing motives on the example of Turkey. It is decided that variables such as sex, income, level of education, and household size are influential in organic food demand. Kaçur (2009) tried to determine how the participant has perceived organic products, and significant differences were found between the participants' way of perceiving organic products and their sex, marital status, title, and the variables of the average income of families. Onurlubaş and Doğan (2016) examined the factors affecting the consumption amounts of organic products and the point of view of the consumers towards organic products, and it was accepted that there was a significant relationship between the sex, marital status, occupation, monthly income, city of residence, the level of knowledge on organic products and the probability to consume organic products (Merdan, 2018: 178). Based on these studies, the sub-hypotheses of the research are formed as follows to find the answer to whether the evaluation on the marketing components of organic cosmetics changed or not according to the socio-demographic qualities of the consumers.

$\mathrm{Hl}^{a}$ : The evaluations of the marketing components of organic cosmetics on prices differ based on the ages of the participants.

$H_{l}{ }^{b}$ : The evaluations of the marketing components of organic cosmetics on the products differ based on the ages of the participants.

$\mathrm{Hl}_{\mathrm{l}}$ : The evaluations of organic cosmetics on the price and promotion techniques differ based on the levels of education of the participants.

$H_{l}{ }^{d}$ : The evaluations of the marketing components of organic cosmetics differ based on the participants' occupation.

$\mathrm{Hl}_{\mathrm{l}}$ : The evaluations of the marketing components of organic cosmetics differ based on the levels of income of the participants.

$H_{l}$ : The evaluations of the marketing components of organic cosmetics differ based on the participants' knowledge.

$\mathrm{Hl}_{l}$ : The evaluations of the marketing components of organic cosmetics differ based on the consumption of organic cosmetics by the participants.

$\mathrm{Hl}_{\mathrm{l}}$ : The evaluations of the marketing components of organic cosmetics on prices differ based on the consideration of organic cosmetics as economical by the participants.

$H l^{l}$ : The evaluations of the marketing components of organic cosmetics differ based on the recommending of organic cosmetics by the participants to others.

$H{ }^{j}$ : The evaluations of organic cosmetics on the product, price, and promotion techniques differ based on the purchasing reasons of the participants.

\subsection{The Reliability Analysis of the Scale in the Research}

The consumer evaluation scale for organic cosmetic products is formed of 13 elements. Kaiser-Meyer-Olkin $(\mathrm{KMO}>0,5)$ and Bartlett sphericity test $(\mathrm{p}<0.05)$ are expected to be statistically significant to understand whether the scale conforms to the factor analysis (Punch, 2005: 124; Kalayc1, 2010: 322). KMO value was calculated as the coefficient of 0.933 , and the Bartlett Sphericity test $X^{2}$ value was calculated as 3748,805 (df: 78 Sig:0,000). The total 
variant explanation rate of the product size among the marketing components was found as $65.719 \%$, and the reliability analysis was found as Cronbach's Alpha 0.901 according to the result of the factor analysis conducted. Nunally (1978) recommends an alpha value of 0,7 while Robinson et al. (1991) and Hair et al. (2006) suggest that a value of 0,6 is acceptable for exploratory research. Accordingly, the reliability level of the product size is high. The data were determined to be following the factor analysis according to $\operatorname{KMO}(0,894>0,5)$ and Bartlett $\left(X^{2}: 2613,403\right.$, df: 36 Sig:0,000<0,05) test results on the pricing of organic cosmetics. The total variant explanation rate of the scale formed of 9 elements was 53.649\%, and the reliability analysis was found as Cronbach's Alpha 0.891 according to the result of the factor analysis conducted. Accordingly, the reliability level of the pricing size is high. The data were determined to be following the factor analysis according to $\operatorname{KMO}(0,755>0,5)$ and Bartlett $\left(X^{2}: 586,874 \mathrm{df}: 10\right.$ Sig:0,000 <0,05) test results on the packaging of organic cosmetics. The total variant explanation rate of the scale formed of 5 elements was found as $51.246 \%$, and the reliability analysis was found as Cronbach's Alpha 0.719 according to the result of the factor analysis conducted. Accordingly, the reliability level of the package size is high. The data were determined to be under the factor analysis according to KMO $(0,825>0,5)$ and Bartlett Sphericity $\left(X^{2}: 1311,979 \mathrm{df}: 45 \mathrm{Sig}: 0,000<0,05\right)$ test results on the promotion techniques of organic cosmetics. According to the result of the factor analysis conducted, the total variant explanation rate of the scale formed of 10 elements was found as $48.339 \%$, according to the result of the factor analysis conducted. The explained variant between $40 \%$ and $60 \%$ are accepted in the social sciences (Kline: 2005; Tavşanc1l, 2005; Bayram, 2009). The reliability coefficient of the consumer evaluation on the promotion techniques of organic cosmetics is Cronbach's Alpha 0.788. Accordingly, the reliability level of the size of promotion techniques is high.

\section{THE RESEARCH FINDING}

\subsection{Socio-Demographic Findings of the Participants}

The data showing the demographic characteristics obtained from the consumers participating in the research are shown in Table 1.

Table 1. The Socio-Demographic Characteristics of The Participants

\begin{tabular}{|c|c|c|c|}
\hline & & $\mathbf{n}$ & $\%$ \\
\hline \multirow{5}{*}{ Age } & $18-26$ & 234 & 40.1 \\
\hline & $27-35$ & 148 & 25.3 \\
\hline & $36-44$ & 134 & 22.9 \\
\hline & $45-56$ & 55 & 9.5 \\
\hline & 57 and older & 12 & 2.2 \\
\hline \multirow{4}{*}{ The Level of education } & Primary School & 116 & 19.8 \\
\hline & High School & 195 & 33.4 \\
\hline & College & 245 & 42.4 \\
\hline & Master's Degree/PhD & 26 & 4.4 \\
\hline \multirow{8}{*}{ Occupation } & Worker & 27 & 4.6 \\
\hline & Public sector officer & 56 & 9.6 \\
\hline & Retired & 17 & 2.9 \\
\hline & Housewife & 226 & 38.7 \\
\hline & Independent business & 10 & 1.7 \\
\hline & Student & 167 & 28.6 \\
\hline & Unemployed & 29 & 5.0 \\
\hline & Private sector employee & 51 & 8.7 \\
\hline \multirow{2}{*}{ Marital Status } & Single & 264 & 45.3 \\
\hline & Married & 319 & 54.7 \\
\hline
\end{tabular}




\begin{tabular}{|c|c|c|c|}
\hline \multirow{5}{*}{ Average monthly net income of the household } & $2500 \mathrm{TL}$ and less & 217 & 37.2 \\
\hline & $2500-4500 \mathrm{TL}$ & 232 & 39.7 \\
\hline & $4501-6500 \mathrm{TL}$ & 78 & 13.3 \\
\hline & $6501-8500 \mathrm{TL}$ & 30 & 5.1 \\
\hline & 8501 and higher & 26 & 4.7 \\
\hline \multirow{2}{*}{ Knowledge of organic cosmetics } & Yes & 410 & 70.3 \\
\hline & No & 173 & 29.7 \\
\hline \multirow{2}{*}{ The consumption status of organic cosmetics } & Yes & 404 & 69.2 \\
\hline & No & 179 & 30.8 \\
\hline \multirow{2}{*}{ The state of finding organic cosmetics economical } & Yes & 118 & 20.2 \\
\hline & No & 465 & 79.8 \\
\hline \multirow{2}{*}{ The state of recommending organic cosmetics to others } & Yes & 512 & 87.9 \\
\hline & No & 71 & 12.1 \\
\hline \multirow{4}{*}{ The reason to buy organic cosmetics } & Needs & 154 & 26.4 \\
\hline & Environment & 36 & 6.2 \\
\hline & Health & 356 & 61.1 \\
\hline & Other & 37 & 6.4 \\
\hline
\end{tabular}

Considering the age variance of the survey participants, it is considered that the participants aged 36 and older will highly contribute to the research in terms of the product experience as they form $34.6 \%$ of the research, and the participants between the ages of 18-35 will contribute to the research in terms of their curiosity and enthusiasm as they form $65.4 \%$ of the research. The linear relationship between the levels of education of the consumers and the consumer awareness (OTA, 2013) means that the consumers' awareness may be high as $42.4 \%$ of the participants graduated from college and 4.4\% completed master's degree and post. $38.7 \%$ of the survey participants are housewives, $24.6 \%$ are employees, and $28.6 \%$ are students. It is considered that the distribution is suitable in terms of occupational variables. According to the marital status variable of the survey participants, it is observed that the rate of single women is higher than the married women. In terms of income level, $62.8 \%$ of the participants are over the average income group. The rate of those knowing organic cosmetics is $70.3 \%$; the rate of those using the same is $69.2 \%$; the rate of those who find them economic is $20.2 \%$; the rate of those who recommend the same to others is $87.9 \%$; the rate of those buying them for health reasons is $61.1 \%$, and the rate of those buying them for necessity is $26.4 \%$. Therefore, the distribution of the socio-demographic data used in this study is healthy and sufficient.

\subsection{Comparative Test Findings of the Participants}

The findings obtained to detect the evaluations of the survey participants on the marketing components of organic cosmetics are as follows. The ANOVA test results that were carried out to examine the evaluations of the marketing components of organic cosmetics in terms of the age variable of the female consumers are as follows.

Table 2. The Evaluation of Organic Cosmetics in Terms of Age

\begin{tabular}{|c|c|c|c|c|c|c|c|}
\hline Age & & $\mathbf{n}$ & Mean & Ss & $\mathbf{F}$ & $\mathbf{p}$ & $\begin{array}{c}\text { Multiple } \\
\text { Comparison }\end{array}$ \\
\hline \multirow{4}{*}{ Consumer Evaluation on the Products } & $18-26$ & 234 & 3.67 & 0.66 & \multirow{4}{*}{2.412} & \multirow{4}{*}{.067} & \\
\hline & $27-35$ & 148 & 3.86 & 0.62 & & & \\
\hline & $36-44$ & 134 & 3.79 & 0.74 & & & \\
\hline & 45 and older & 67 & 3.76 & 0.91 & & & \\
\hline \multirow{4}{*}{ Consumer Evaluation on the Price } & $18-26$ & 234 & 3.94 & 0.80 & \multirow{4}{*}{3.313} & \multirow{4}{*}{$.020^{*}$} & \multirow{4}{*}{$1<4$} \\
\hline & $27-35$ & 148 & 4.06 & 0.75 & & & \\
\hline & $36-44$ & 134 & 4.10 & 0.76 & & & \\
\hline & 45 and older & 67 & 4.25 & 0.79 & & & \\
\hline
\end{tabular}




\begin{tabular}{|c|c|c|c|c|c|c|}
\hline \multirow{4}{*}{ Consumer Evaluation on the Packaging } & $18-26$ & 234 & 3.35 & 0.73 & \multirow{4}{*}{0.525} & \multirow{4}{*}{.666} \\
\hline & $27-35$ & 148 & 3.42 & 0.71 & & \\
\hline & $36-44$ & 134 & 3.31 & 0.83 & & \\
\hline & 45 and older & 67 & 3.33 & 0.87 & & \\
\hline \multirow{4}{*}{$\begin{array}{l}\text { Consumer Evaluation on the Promotion } \\
\text { Techniques }\end{array}$} & $18-26$ & 234 & 3.59 & 0.62 & \multirow{4}{*}{0.610} & \multirow{4}{*}{.609} \\
\hline & $27-35$ & 148 & 3.65 & 0.57 & & \\
\hline & $36-44$ & 134 & 3.60 & 0.75 & & \\
\hline & 45 and older & 67 & 3.69 & 0.77 & & \\
\hline
\end{tabular}

$* \mathbf{p}<\mathbf{0 . 0 5}$

A statistically significant difference was found between the evaluation on the prices of the female consumers of different ages $(\mathrm{p}<0.05)$. Accordingly, the mean score of the women aged 45 and older is the highest, and the mean value decreases based on age. The t-test results that were carried out to examine the evaluations of the marketing components of organic cosmetics in terms of the marital status variable of the female consumers are as follows.

Table 3. The Evaluation of Organic Cosmetics in terms of Marital Status

\begin{tabular}{|c|c|c|c|c|c|c|}
\hline Marital Status & & $\mathbf{n}$ & Mean & SS & $\mathbf{t}$ & p \\
\hline \multirow{2}{*}{ Consumer Evaluation on the Products } & Single & 264 & 3.71 & 0.63 & \multirow{2}{*}{-1.673} & \multirow{2}{*}{$.036^{*}$} \\
\hline & Married & 319 & 3.81 & 0.75 & & \\
\hline \multirow{2}{*}{ Consumer Evaluation on the Price } & Single & 264 & 4.01 & 0.72 & \multirow{2}{*}{-1.124} & \multirow{2}{*}{.065} \\
\hline & Married & 319 & 4.08 & 0.81 & & \\
\hline \multirow{2}{*}{ Consumer Evaluation on the Packaging } & Single & 264 & 3.38 & 0.72 & \multirow{2}{*}{0.786} & \multirow{2}{*}{.086} \\
\hline & Married & 319 & 3.33 & 0.79 & & \\
\hline \multirow{2}{*}{ Consumer Evaluation on the Promotion Techniques } & Single & 264 & 3.61 & 0.63 & \multirow{2}{*}{-0.067} & \multirow{2}{*}{.054} \\
\hline & Married & 319 & 3.62 & 0.68 & & \\
\hline
\end{tabular}

*p $<0.05$

There is a statistically significant difference in terms of product evaluations among female consumers with different marital status $(\mathrm{p}<0.05)$. Accordingly, the mean score of the married women is higher. There is a statistically significant difference in terms of price evaluations among female consumers with different marital status. The ANOVA test results that were carried out to examine the evaluations of the marketing components of organic cosmetics in terms of the level of education variable of the female consumers are as follows.

Table 4. The Evaluation of Organic Cosmetics in terms of The Level of Education

\begin{tabular}{|c|c|c|c|c|c|c|c|}
\hline The level of education & & $\mathbf{n}$ & Mean & ss & $\mathbf{F}$ & $\mathbf{p}$ & $\begin{array}{c}\text { Multiple } \\
\text { Comparison }\end{array}$ \\
\hline \multirow{4}{*}{ Consumer Evaluation on the Products } & Primary School & 116 & 3.91 & 0.77 & \multirow{4}{*}{3.278} & \multirow{4}{*}{$.005^{*}$} & \multirow{4}{*}{$\begin{array}{l}1>2 \\
1>4\end{array}$} \\
\hline & High School & 195 & 3.70 & 0.77 & & & \\
\hline & College & 245 & 3.73 & 0.59 & & & \\
\hline & Master's Degree/PhD & 26 & 3.48 & 0.87 & & & \\
\hline \multirow{4}{*}{ Consumer Evaluation on the Price } & Primary School & 116 & 4.18 & 0.87 & \multirow{4}{*}{1.302} & \multirow{4}{*}{.238} & \\
\hline & High School & 195 & 3.97 & 0.84 & & & \\
\hline & College & 245 & 4.04 & 0.70 & & & \\
\hline & Master's Degree/PhD & 26 & 4.05 & 0.59 & & & \\
\hline \multirow{4}{*}{$\begin{array}{l}\text { Consumer Evaluation on the } \\
\text { Packaging }\end{array}$} & Primary School & 116 & 3.56 & 0.83 & \multirow{4}{*}{5.822} & \multirow{4}{*}{$.000 *$} & \multirow{4}{*}{$1>3$} \\
\hline & High School & 195 & 3.40 & 0.78 & & & \\
\hline & College & 245 & 3.23 & 0.67 & & & \\
\hline & Master's Degree/PhD & 26 & 3.16 & 0.90 & & & \\
\hline
\end{tabular}




\begin{tabular}{|c|c|c|c|c|c|c|c|}
\hline \multirow{4}{*}{$\begin{array}{l}\text { Consumer Evaluation on the } \\
\text { Promotion Techniques }\end{array}$} & Primary School & 116 & 3.72 & 0.69 & \multirow{4}{*}{2.245} & \multirow{4}{*}{$.047^{*}$} & \multirow{4}{*}{$1>4$} \\
\hline & High School & 195 & 3.64 & 0.71 & & & \\
\hline & College & 245 & 3.55 & 0.58 & & & \\
\hline & Master's Degree/PhD & 26 & 3.42 & 0.63 & & & \\
\hline
\end{tabular}

Statistically, a significant difference is found between evaluating the products of the female consumers with different levels of education $(\mathrm{p}<0.05)$. Accordingly, the mean score of the women who graduated from primary school is the highest, while the mean score of the women who graduated from a master's Degree/Ph.D. program is the lowest. Statistically, a significant difference is found between the evaluation on the packaging of the female consumers with different levels of education $(\mathrm{p}<0.05)$. Accordingly, the mean score of the women who graduated from primary school is the highest, and the mean score decreases based on the increase in the level of education. Statistically, a significant difference is found between evaluating the promotion techniques of the female consumers with different levels of education $(\mathrm{p}<0.05)$. Accordingly, the mean score of the women who graduated from primary school is the highest, and the mean score decreases based on the increase in the level of education.

The ANOVA test results that were carried out to examine the evaluations of the marketing components of organic cosmetics in terms of the average monthly income variable of the female consumers are as follows.

Table 5. The Evaluation of Organic Cosmetics in Terms of Average Monthly Net Income of The Household

\begin{tabular}{|c|c|c|c|c|c|c|}
\hline Average monthly income of the household & & $\mathbf{n}$ & Mean & ss & $\mathbf{F}$ & $\mathbf{p}$ \\
\hline \multirow{5}{*}{ Consumer Evaluation on the Products } & Under $2500 \mathrm{TL}$ & 217 & 3.74 & 0.79 & \multirow{5}{*}{.927} & \multirow{5}{*}{.448} \\
\hline & $2500-4500 \mathrm{TL}$ & 232 & 3.74 & 0.67 & & \\
\hline & $4501-6500 \mathrm{TL}$ & 78 & 3.85 & 0.67 & & \\
\hline & $6501-8500 \mathrm{TL}$ & 30 & 3.91 & 0.52 & & \\
\hline & 8501 and over & 26 & 3.65 & 0.51 & & \\
\hline \multirow{5}{*}{ Consumer Evaluation on the Price } & Under $2500 \mathrm{TL}$ & 217 & 4.08 & 0.81 & \multirow{5}{*}{.332} & \multirow{5}{*}{.857} \\
\hline & $2500-4500 \mathrm{TL}$ & 232 & 4.03 & 0.78 & & \\
\hline & $4501-6500 \mathrm{TL}$ & 78 & 4.06 & 0.77 & & \\
\hline & $6501-8500 \mathrm{TL}$ & 30 & 4.18 & 0.60 & & \\
\hline & 8501 and over & 26 & 3.99 & 0.59 & & \\
\hline \multirow{5}{*}{ Consumer Evaluation on the Packaging } & Under $2500 \mathrm{TL}$ & 217 & 3.34 & 0.83 & \multirow{5}{*}{1.872} & \multirow{5}{*}{.114} \\
\hline & $2500-4500 \mathrm{TL}$ & 232 & 3.38 & 0.75 & & \\
\hline & $4501-6500 \mathrm{TL}$ & 78 & 3.47 & 0.68 & & \\
\hline & $6501-8500 \mathrm{TL}$ & 30 & 3.32 & 0.47 & & \\
\hline & 8501 and over & 26 & 3.01 & 0.61 & & \\
\hline \multirow{5}{*}{ Consumer Evaluation on the Promotion Techniques } & Under $2500 \mathrm{TL}$ & 217 & 3.65 & 0.70 & \multirow{5}{*}{1.543} & \multirow{5}{*}{.188} \\
\hline & $2500-4500 \mathrm{TL}$ & 232 & 3.60 & 0.66 & & \\
\hline & $4501-6500 \mathrm{TL}$ & 78 & 3.71 & 0.60 & & \\
\hline & $6501-8500 \mathrm{TL}$ & 30 & 3.59 & 0.39 & & \\
\hline & 8501 and over & 26 & 3.37 & 0.52 & & \\
\hline
\end{tabular}

*p $<0.05$

There is no statistically significant difference between the evaluations of the female consumers with additional monthly average household income on the marketing components of organic cosmetics ( $>0.05)$. The ANOVA test results that were carried out to examine the evaluations of the marketing components of organic cosmetics in terms of the occupation variable of the female consumers are as follows. 
Table 6. The Evaluation of Organic Cosmetics in terms of Occupation

\begin{tabular}{|c|c|c|c|c|c|c|}
\hline Occupation & & $\mathbf{n}$ & Mean & SS & $\mathbf{F}$ & $\mathbf{p}$ \\
\hline \multirow{8}{*}{ Consumer Evaluation on the Products } & Worker & 27 & 3.64 & 0.97 & \multirow{8}{*}{2,011} & \multirow{8}{*}{.052} \\
\hline & Public sector officer & 56 & 3.80 & 0.54 & & \\
\hline & Retired & 17 & 4.19 & 0.65 & & \\
\hline & Housewife & 226 & 3.77 & 0.74 & & \\
\hline & Independent business & 10 & 3.49 & 1.12 & & \\
\hline & Student & 167 & 3.64 & 0.73 & & \\
\hline & Unemployed & 29 & 3.75 & 0.59 & & \\
\hline & Private sector employee & 51 & 3.87 & 0.58 & & \\
\hline \multirow{8}{*}{ Consumer Evaluation on the Price } & Worker & 27 & 3.92 & 0.69 & \multirow{8}{*}{1.243} & \multirow{8}{*}{.277} \\
\hline & Public sector officer & 56 & 4.05 & 0.57 & & \\
\hline & Retired & 17 & 4.52 & 0.54 & & \\
\hline & Housewife & 226 & 4.05 & 0.86 & & \\
\hline & Independent business & 10 & 4.10 & 0.58 & & \\
\hline & Student & 167 & 3.97 & 0.84 & & \\
\hline & Unemployed & 29 & 4.08 & 0.61 & & \\
\hline & Private sector employee & 51 & 4.13 & 0.72 & & \\
\hline \multirow{8}{*}{ Consumer Evaluation on the Packaging } & Worker & 27 & 3.48 & 0.95 & \multirow{8}{*}{0.552} & \multirow{8}{*}{.795} \\
\hline & Public sector officer & 56 & 3.27 & 0.71 & & \\
\hline & Retired & 17 & 3.40 & 0.62 & & \\
\hline & Housewife & 226 & 3.36 & 0.82 & & \\
\hline & Independent business & 10 & 3.16 & 1.02 & & \\
\hline & Student & 167 & 3.34 & 0.75 & & \\
\hline & Unemployed & 29 & 3.25 & 0.69 & & \\
\hline & Private sector employee & 51 & 3.47 & 0.62 & & \\
\hline \multirow{8}{*}{ Consumer Evaluation on the Promotion Techniques } & Worker & 27 & 3.58 & 0.79 & \multirow{8}{*}{0.964} & \multirow{8}{*}{.457} \\
\hline & Public sector officer & 56 & 3.55 & 0.56 & & \\
\hline & Retired & 17 & 3.97 & 0.62 & & \\
\hline & Housewife & 226 & 3.63 & 0.72 & & \\
\hline & Independent business & 10 & 3.59 & 0.79 & & \\
\hline & Student & 167 & 3.57 & 0.67 & & \\
\hline & Unemployed & 29 & 3.67 & 0.45 & & \\
\hline & Private sector employee & 51 & 3.67 & 0.53 & & \\
\hline
\end{tabular}

${ }^{*} \mathbf{p}<\mathbf{0 . 0 5}$

There is no statistically significant difference between the evaluations of the female consumers with different occupations on the marketing components of organic cosmetics $(p>0.05)$. The t-test results that were carried out to examine the evaluations of the marketing components of organic cosmetics in terms of the knowledge variable of the female consumers are as follows.

Table 7. The Evaluation of Organic Cosmetics in terms of Knowledge

\begin{tabular}{lcccccc}
\hline Knowledge of organic cosmetics & & $\mathbf{n}$ & Mean & ss & t & $\mathbf{p}$ \\
\hline Consumer Evaluation on the Products & Yes & 410 & 3.77 & 0.68 & 0.520 & .594 \\
& No & 173 & 3.70 & 0.77 & \\
\hline Consumer Evaluation on the Price & Yes & 410 & 4.04 & 0.76 & 0.062 & .956 \\
\hline
\end{tabular}




\begin{tabular}{lcccccc} 
& No & 173 & 4.03 & 0.85 & \\
\hline Consumer Evaluation on the Packaging & Yes & 410 & 3.39 & 0.74 & 1.658 & .104 \\
\hline Consumer Evaluation on the Promotion Techniques & No & 173 & 3.26 & 0.81 & \\
\hline
\end{tabular}

*p $<0.05$

There is no statistically significant difference between the evaluations of the female consumers having knowledge and not knowing the marketing components of organic cosmetics $(\mathrm{p}>0.05)$. The t-test results that were carried out to examine the evaluations of the marketing components of organic cosmetics in terms of the consumption status of organic cosmetics variable of the female consumers are as follows.

Table 8. The Evaluation of Organic Cosmetics in terms of Consumption Status

\begin{tabular}{|c|c|c|c|c|c|c|}
\hline Consumption Status of Organic Cosmetics & & $\mathbf{n}$ & Mean & ss & $\mathbf{t}$ & $\mathbf{p}$ \\
\hline \multirow{2}{*}{ Consumer Evaluation on the Products } & Yes & 404 & 3.73 & 0.72 & \multirow{2}{*}{-1.592} & \multirow{2}{*}{.112} \\
\hline & No & 179 & 3.83 & 0.69 & & \\
\hline \multirow{2}{*}{ Consumer Evaluation on the Price } & Yes & 404 & 4.01 & 0.80 & \multirow{2}{*}{-1.421} & \multirow{2}{*}{.156} \\
\hline & No & 179 & 4.11 & 0.77 & & \\
\hline \multirow{2}{*}{ Consumer Evaluation on the Packaging } & Yes & 404 & 3.36 & 0.76 & \multirow{2}{*}{,- 034} & \multirow{2}{*}{.973} \\
\hline & No & 179 & 3.37 & 0.79 & & \\
\hline \multirow{2}{*}{ Consumer Evaluation on the Promotion Techniques } & Yes & 404 & 3.60 & 0.67 & \multirow{2}{*}{,- 899} & \multirow{2}{*}{.369} \\
\hline & No & 179 & 3.66 & 0.64 & & \\
\hline
\end{tabular}

\section{*p $<0.05$}

Whether the female participants consume organic cosmetics does not cause a statistically significant difference in their evaluation of the marketing components $(p>0.05)$. The t-test results that were carried out to examine the evaluations of the marketing components of organic cosmetics regarding the women finding organic cosmetics economic are as follows.

Table 9. The Evaluation of Organic Cosmetics in terms of Finding It Economical

\begin{tabular}{|c|c|c|c|c|c|c|}
\hline The state of finding organic cosmetics economical & & $\mathbf{n}$ & Mean & SS & $\mathbf{t}$ & $\mathbf{p}$ \\
\hline \multirow{2}{*}{ Consumer Evaluation on the Products } & Yes & 118 & 3.79 & 0.79 & \multirow{2}{*}{0.383} & \multirow{2}{*}{.702} \\
\hline & No & 465 & 3.76 & 0.68 & & \\
\hline \multirow{2}{*}{ Consumer Evaluation on the Price } & Yes & 118 & 3.86 & 0.81 & \multirow{2}{*}{-3.118} & \multirow{2}{*}{$.000^{*}$} \\
\hline & No & 465 & 4.11 & 0.75 & & \\
\hline \multirow{2}{*}{ Consumer Evaluation on the Packaging } & Yes & 118 & 3.48 & 0.87 & \multirow{2}{*}{1.750} & \multirow{2}{*}{.082} \\
\hline & No & 465 & 3.33 & 0.73 & & \\
\hline \multirow{2}{*}{ Consumer Evaluation on the Promotion Techniques } & Yes & 118 & 3.60 & 0.74 & \multirow{2}{*}{-0.574} & \multirow{2}{*}{.566} \\
\hline & No & 465 & 3.64 & 0.64 & & \\
\hline
\end{tabular}

${ }^{*} \mathbf{p}<0.05$

There is no statistically significant difference in evaluating the female consumers finding organic cosmetics economical and the female consumers not finding organic cosmetics economical on the price among the marketing components $(\mathrm{p}<0.05)$. Accordingly, the mean score of the women finding organic cosmetics economical is higher than the mean score of the women finding organic cosmetics economical. The results of the t-test that was carried out to examine the evaluations of the marketing components of organic cosmetics in terms of the recommendation by 
female consumers to others are as follows.

Table 10. The Evaluation of Organic Cosmetics in terms of The Status of recommending to Others.

\begin{tabular}{lcccccc}
\hline The Status of recommending Organic Cosmetics to Others & & $\mathbf{n}$ & Mean & ss & t & p \\
\hline Consumer Evaluation on the Products & Yes & 512 & 3.83 & 0.65 & 5.097 & $.000^{*}$ \\
\hline Consumer Evaluation on the Price & No & 71 & 3.38 & 0.88 & \\
\hline Consumer Evaluation on the Packaging & Yes & 512 & 4.11 & 0.74 & 3.672 & $.000^{*}$ \\
& No & 71 & 3.75 & 0.98 & & \\
\hline Consumer Evaluation on the Promotion Techniques & Yes & 512 & 3.42 & 0.71 & 4.956 & $.000^{*}$ \\
& No & 71 & 2.95 & 0.95 & & \\
\hline
\end{tabular}

$* \mathbf{p}<\mathbf{0 . 0 5}$

It was found that the evaluations of the female consumers on the products, prices, package, promotion techniques according to the status of recommending organic cosmetics to others showed statistically significant difference $(\mathrm{p}<0.05)$. Accordingly, the participants' mean score recommending the same to others is higher than those who do not recommend. The ANOVA test results that were carried out to examine the evaluations of the marketing components of organic cosmetics in terms of the reasons of the participants to purchase organic cosmetics are as follows.

Table 11. The Evaluation of Organic Cosmetics in terms of The Reason for Purchasing

\begin{tabular}{|c|c|c|c|c|c|c|c|}
\hline Reason to Purchase Organic Cosmetics & & $\mathbf{n}$ & Mean & ss & $\mathbf{F}$ & $\mathbf{p}$ & $\begin{array}{c}\text { Multiple } \\
\text { Comparison } \\
\end{array}$ \\
\hline \multirow{4}{*}{ Consumer Evaluation on the Products } & Needs & 154 & 3.61 & 0.74 & \multirow{4}{*}{4.762} & \multirow{4}{*}{$.003 *$} & \multirow{4}{*}{$1<3$} \\
\hline & Environment & 36 & 3.64 & 0.75 & & & \\
\hline & Health & 356 & 3.85 & 0.69 & & & \\
\hline & Other & 37 & 3.73 & 0.67 & & & \\
\hline \multirow{4}{*}{ Consumer Evaluation on the Price } & Needs & 154 & 3.87 & 0.85 & \multirow{4}{*}{-5.615} & \multirow{4}{*}{$.001^{*}$} & \multirow{4}{*}{$1<3$} \\
\hline & Environment & 36 & 4.02 & 0.60 & & & \\
\hline & Health & 356 & 4.15 & 0.75 & & & \\
\hline & Other & 37 & 3.82 & 0.93 & & & \\
\hline \multirow{4}{*}{ Consumer Evaluation on the Packaging } & Needs & 154 & 3.35 & 0.72 & \multirow{4}{*}{-0.713} & \multirow{4}{*}{.545} & \\
\hline & Environment & 36 & 3.22 & 0.59 & & & \\
\hline & Health & 356 & 3.40 & 0.77 & & & \\
\hline & Other & 37 & 3.31 & 0.96 & & & \\
\hline \multirow{4}{*}{ Consumer Evaluation on the Promotion Techniques } & Needs & 154 & 3.50 & 0.68 & \multirow{4}{*}{3.181} & \multirow{4}{*}{$.024 *$} & \multirow{4}{*}{$1<3$} \\
\hline & Environment & 36 & 3.60 & 0.59 & & & \\
\hline & Health & 356 & 3.69 & 0.65 & & & \\
\hline & Other & 37 & 3.58 & 0.69 & & & \\
\hline
\end{tabular}

$* \mathbf{p}<0.05$

It was determined that the evaluations of the female consumers based on the product, price, promotion techniques according to purchasing organic cosmetics showed statistically significant difference $(p<0.05)$. The mean score of the female consumers purchasing organic cosmetics due to health reasons is higher than the female consumers purchasing organic cosmetics due to needs. 


\section{THE DISCUSSION AND RESULT}

The consumer evaluations concerning organic cosmetics are important in determining the current and potential consumers with theoretical and practical significance and understanding the same for the marketing people. The evaluations of the female consumers participating in the research on the marketing components within the frame of their socio-demographic characteristics are stated in this study. It can be said that the consumers aged between 27 and 44 are predominant (48.2\%), those are followed by the younger participants (40.1\%), and the consumers aged over 45 (11.7\%) are less based on the socio-demographical characteristics of the participants. It can be said that there is no difference between the evaluations of the participants on organic cosmetics concerning the product, packaging, and the promotion techniques; however, there is a difference based on the price evaluations and that this difference arises from the fact that the consumers aged 45 and older are more sensitive to price than the consumers aged between 1826 according to the age variable. It was stated by Essoussi and Zahaf (2008) that the consumers of different age groups had different purchasing motives. It was detected those old consumers act with the health motive Magnusson et al. (2001) however, they consume less Rimal et al. (2005) in their decision to purchase organic products although they have the power to purchase. It was observed that more than half of the participants were married; the price, package, and promotion techniques of organic cosmetics are not different based on the marital status variable; however, the emerging difference showed that married women attributed more importance to their evaluations of the product compared to the single women. It can be said that married women attributed importance to organic cosmetics for themselves and their husbands and children. The level of education of the limited number of participants is low. Storstad and Bjorkhaug (2003) revealed that the consumers purchase organics with a high level of education. It is found that there is no difference between the evaluations of the consumers with different levels of education based on the price. It is observed that the difference in the other components arises from the fact that the consumers with a low level of education make more positive evaluations on the product, packaging, and promotion techniques compared to the consumers with a high level of education. Rimal et al. (2005) presented that the consumers' household income level affected the consumers' organic product consumption positively. Similarly, Turjusen et al. (2001) determined that the consumers purchase more organic food in parallel to the increase in their income. It is observed that the income levels of the majority of the participants are over the level of minimum income in this study. It is detected that there is no difference between their evaluation of the marketing components of organic cosmetics based on their level of income and their occupation according to the findings obtained. It is detected that the majority of the participants (70.3\%) know organic cosmetics. It is detected in the study of Ghazali et al. (2017) that a high level of knowledge on organic cosmetics is effective over the repetitive purchasing attitude. However, it is seen that there is no variability based on the knowledge. The majority of the participants tried organic cosmetics; however, no difference was found between their evaluations based on their consumption. The participants who do not find organic cosmetics economic are found as $(79.8 \%)$. The perception that the price of organic products is higher than the other products due to their costs, and therefore they appeal to the group with a high level of income, is remarkable (Zanoli and Naspetti, 2002). However, it is found that the consumers who do not find the price component economic are more positive than the consumers who find them economical. It can be said that this is the result of the perception of the high price as the high quality (Monreo, 1973). The rate of the participants who recommend organic cosmetics that they previously used or they currently use is detected to be $(69.2 \%)$. It is concluded that the participants 
recommending organic cosmetics to others evaluated the marketing components positively compared to those who do not recommend the same. It can also be said for this study that the consumers are in an intensive sharing concerning the products and services. Onyango et al. (2007) presented those young consumers are more eager to purchase organic products as their interest in environmental issues more intense than old customers. It is seen that the most important reason behind the participants' purchasing organic cosmetics is health, followed by needs, as seen in the study of Hamilton and Hekmat (2018), environment Chan (1999), and special offers, promotions, and other reasons. It can be said that the difference in the participants' evaluations for the product, price, and promotion techniques among the marketing components may arise from the fact that they are more sensitive to health compared to needs. Hughner et al. (2007) presented that the female consumers concerned about their health have a higher intention to purchase organic cosmetic products. Among the hypotheses formed due to the analyses conducted, $\mathrm{H}_{1} \mathrm{a}, \mathrm{H}_{1} \mathrm{~b}, \mathrm{H}_{1} \mathrm{c}$, $\mathrm{H}_{1} h, \mathrm{H}_{1} \mathrm{i}, \mathrm{H}_{1} \mathrm{j}$ were (accepted), while $\mathrm{H}_{1} \mathrm{~d}, \mathrm{H}_{1} \mathrm{e}, \mathrm{H}_{1} \mathrm{f}, \mathrm{H}_{1} \mathrm{~g}$ were (declined). This study was prepared to contribute to the marketing literature as it was noticed that few studies concerning organic cosmetic products.

\section{Suggestion}

The marketing activities promoting sustainable consumption support the current and future life quality of the current and potential consumers and provide organic products to reach large masses. It was tried to present the necessity for the marketing experts to consider the consumers' evaluation while performing product development, packaging, pricing, and promotion activities. The studies to be conducted in the field will enable understanding the consumer behavior, directing the industry performers, and having a better understanding and use upon the gradual increase in organic consumption. Domestic sales and overseas sales may be increased by first developing the regional recognition of the locomotive products by increasing the awareness for the regional organic products. As the young generation decreases in the west and increases in Turkey, it is stipulated that the cosmetic spending per capita will boom in Turkey shortly (Çomoğlu, 2012: 2). Furthermore, Turkey has a convenient potential for adding plants/plantbased raw materials with the potential to use in the cosmetics field (Ergin ve Kartal, 2016: 13). Therefore it is considered that transition to domestic production in cosmetics can increase the consumer demand and provide the development of the market by planned studies.

\section{Limitedness}

This study is prepared to understand whether the participants in Malatya province support the transition to organic cosmetic market and to be a preliminary study for another research that may be conducted. This study does not cover the general consumer trend. It only focuses on the female consumers residing in Malatya province. Studies in the literature show that women show more interest than men in organic products (Thompson, 1998; Yiridoe et al., 2005; Costa et al., 2014). Therefore, this study is limited to female consumers. 


\section{ANNEX- Consumer Evaluation Scale for The Marketing Components of Organic Cosmetics}

\begin{tabular}{|c|c|}
\hline Size & Article \\
\hline \multirow{13}{*}{$\begin{array}{l}\text { Consumer Evaluation } \\
\text { on the Products }\end{array}$} & 1. Utility value of organic cosmetics is high. \\
\hline & 2. Organic cosmetics are healthier than classical products. \\
\hline & 3. I am happy to use organic cosmetics. \\
\hline & 4. Consuming organic products are more suitable for human health. \\
\hline & 5. Consuming organic cosmetics is safer than consuming classical products. \\
\hline & 6. The most important reason I prefer organic cosmetics is their limited hazardous effects on human health. \\
\hline & 7. Organic cosmetics are more effective than classical products. \\
\hline & 8. More production fields should be provided, and support should be given to organic cosmetics. \\
\hline & 9. Organic cosmetics are of incentive quality compared to classical products. \\
\hline & 10. Organic cosmetics are more satisfying than classical products. \\
\hline & 11. Organic cosmetics have better quality than classical products. \\
\hline & 12. Organic cosmetics cannot be found everywhere, unfortunately. \\
\hline & 13. I cannot have the effect that I wish as there is limited diversity in organic cosmetics. \\
\hline \multirow{9}{*}{$\begin{array}{l}\text { Consumer Evaluation } \\
\text { on Price }\end{array}$} & 14. I think the prices of organic cosmetics are very high. \\
\hline & 15. I cannot always prefer organic cosmetics as their prices are very high. \\
\hline & 16. I think there is a price difference between classical products and organic cosmetics. \\
\hline & 17. I think there should be a price standard for organic cosmetics. \\
\hline & $\begin{array}{l}\text { 18. I think that the prices of organic cosmetics should be taken to a reasonable level, and therefore the consumption of } \\
\text { organic products should be increased to protect public health and posterity. }\end{array}$ \\
\hline & 19. I think there is different pricing in each place where organic cosmetics are sold. \\
\hline & 20. I find the prices of organic cosmetics high based on my economic income level. \\
\hline & 21. As organic cosmetics are preferred; sellers mark up the prices of organic products in their favor. \\
\hline & $\begin{array}{l}\text { 22. I think the State should support the production of organic cosmetics, and the prices should be maintained at } \\
\text { reasonable levels to protect public health and the health of prosperity. }\end{array}$ \\
\hline \multirow{5}{*}{$\begin{array}{l}\text { Consumer Evaluation } \\
\text { on the Packaging }\end{array}$} & 23. I find the packages of organic cosmetics safe due to their eco-labels. \\
\hline & 24. I think the packages of the classic cosmetics are not healthy. \\
\hline & 25. I find the packages of organic cosmetics more classical and natural. \\
\hline & 26. I think packaging and storage methods of organic cosmetics are not hazardous to nature and the environment. \\
\hline & 27. I think the packages of classical cosmetics are more attractive compared to organic cosmetics. \\
\hline \multirow{10}{*}{$\begin{array}{l}\text { Consumer Evaluation } \\
\text { on the Promotion } \\
\text { Techniques }\end{array}$} & 28. I think organic cosmetics should be supported by tv, radio, newspaper, internet, and other communication tools. \\
\hline & 29. I do not think sufficient promotion and advertisement activities are performed for organic cosmetics. \\
\hline & 30. I think the sellers of organic cosmetics use effective sales techniques in order for the consumers to purchase them. \\
\hline & 31. The promotion techniques of organic cosmetics attract my attention to organic products. \\
\hline & 32. I think there are more advertisements for classical products compared to organic cosmetics. \\
\hline & $\begin{array}{l}\text { 33. The promotions and advertisements concerning organic cosmetics about health and the environment are highly } \\
\text { effective. }\end{array}$ \\
\hline & $\begin{array}{l}\text { 34. I see the promotions encouraging the sales concerning organic cosmetics only in the supermarkets and at the sales } \\
\text { points. }\end{array}$ \\
\hline & 35. I believe that promotion methods such as advertisements etc., are encouraging in organic cosmetics. \\
\hline & $\begin{array}{l}\text { 36. The promotions and advertisements for classical products prevent the consumers from tending to organic } \\
\text { cosmetics. }\end{array}$ \\
\hline & $\begin{array}{l}\text { 37. I find the promotions and advertisements of organic cosmetics attractive as I am fed up with the promotions and } \\
\text { advertisements concerning classical products. }\end{array}$ \\
\hline
\end{tabular}




\section{REFERENCES}

Ahmad, S. N., \& Juhdi, N. (2010). Organic food: A study on demographic characteristics and factors influencing purchase intentions among consumers in Klang Valley, Malaysia. International Journal of Business and Management, 5(2), 105-118.

Armstrong, G., \& Kotler, P. (2008). Marketing an Introduction. 8th Ed., New Jersey: Pearson- Prentice Hall.

Arslan, M. F. (2004). Mağazacıllkta Atmosfer. İstanbul: Derin Yayınları.

Batte M., Beaverson J., \& Hooker N. (2003). Organic food labels: A customer intercept survey of central Ohio food shoppers. Report Series: AEDE-RP-0038-03, 6-10.

Bayram, N. (2009). Sosyal Bilimlerde SPSS ile Veri Analizi. Bursa: Ezgi Kitabevi.

Bozga N. A. (2015). The perception of romanian consumer upon organic products' prices. Procedia Economics and Finance (27), 323 - 333.

Cengiz, A. (2011). Organik tarım ürünlerini neden tercih etmeliyiz? 5 Nisan 2020 tarihinde http://www.tuder.net/index.php adresinden erişildi.

Çelik, S. (2013). Kimler, neden organik gıda satın alıyor? Bir alan araştırması. Selçuk Üniversitesi Sosyal Bilimler Enstitüsü Dergisi, (30), 93-108.

Çomoğlu, T. (2012). Kozmetikler. Marmara Pharmaceutical Journal, (16), 1-8.

Costa, C., García-Lestón, J., Costa, S., Coelho, P., Silva, S., Pingarilho, M., Valdiglesias, V., Mattei, F., Dall’Armi, V., Bonassi, S., Laffon, B., Snawder, J., Teixeira, J.P., (2014). Is organic farming safer to farmers' health? A comparison between organic and traditional farming. Toxicol. Lett. 230, 166-176.

Chan, K. (1999). Market segmentation of green consumers in Hong Kong. Journal of International Consumer Marketing, $12(2), 7-24$.

Chinnici, G., D'amico, M., \& Pecorino, B. (2002). A multivariate statistical analysis on the consumers of organic products. British Food Journal, 104(3/4/5), 187-199.

Ergin, G., \& Kartal M. (2016). Bitkisel hammaddelerde kozmetik kalite. 6.Kozmetik Kimyası, Üretimi ve Standardizasyonu Kongresi, Istanbul, 26-28 Şubat 2016, 13.

Ersoy Yildırım, A (2020). Investigation of marketing components affecting the evaluation of female consumers about organic cosmetic products. Journal of Business Research Turk, 12(3), 3225-3245.

Essoussi, L. H., \& Zahaf, M. (2008). Decision making process of community organic food consumers: an exploratory study. Journal of Consumer Marketing, 25(2), 95-104.

FIBL \& IFOAM (2019). Organics international. The world of organic agriculture, Germany.

Ghazali, E., Soon, P. C., Mutum, D. S., \& Nguyen, B. (2017). Health and cosmetics: Investigating consumers' values for buying organic personal care products. Journal of Retailing and Consumer Services, (39), 154-163.

Hair, J., Black, W., Babin, B., Anderson, R. E. (2006). Mutivariate Data Analysis Publisher. Pearson Prentice Hall.

Hamilton, K., \& Hekmat, S. (2018). Organic food and university students: a pilot study. Nutrition \& Food Science, 48(2), 218- 227.

Hughner, R. S., Mcdonagh, P., Prothero, A., Shultz, C. J., \& Stanton, J. (2007). Who are organic food consumers? A compilation and review of why people purchase organic food?. Journal of Consumer Behaviour, (6), 1-17.

İslamoğlu, A. H. (1999). Pazarlama Yönetimi. İstanbul: Beta Yayıncılık.

İstanbul Sanayi Odası (ISO) (2011). Avrupa Birliğine uyum sürecinde sektör rehberleri: Temizlik ürünleri ve kozmetik sanayii, Avrupa işletmeler ağı, İstanbul: İstanbul Sanayi Odası Yayınları No: 7.

Johri, L. M., \& Sahasakmontri, K. (1998). Green marketing of cosmetics and toiletries in Thailand. Journal of Consumer Marketing, 15(3), 265-281.

Kaçur, L. L. (2009). Erciyes Üniversitesi İIBF akademik ve idari personeli ile İ̈BF işletme gündüz ve ikinci öğretim öğrencilerinin organik ürünleri algılamaları. Erciyes Üniversitesi İktisadi ve İdari Bilimler Fakültesi Dergisi, (33), 249-277.

Kalayc1, Ş. (2010). SPSS Uygulamalı Çok Değişkenli İstatistik Teknikleri. Ankara: Asil Yayınevi. 
Keller, K. L. (1993). Conceptualizing, measuring, and managing customer-based brand equity. Journal of Marketing, 57, $1-22$.

Kılıç, S., Duman, O. ve Bektaş, E. (2014). Organik ürünlerin pazarlama stratejileri ve işletmeler üzerinde bir alan araştırmas1. Business And Economics Research Journal, 5(1), 39-65.

Kim, H., \& Chung, J. (2011). Consumer purchase intention for organic personal care products. Journal of Consumer Marketing, 28 (1), 40-47.

Kotler, P., \& Keller, K. (2012). Marketing Management. 14th edition. New Jersey: Upper Saddle River, Prentice Hall.

Kunst A. (2019). U.S. consumers who prefer to buy natural/organic cosmetics products 2017. 20 Aralık 2019 tarihinde https://www.statista.com/statistics/713580/cosmetics-natural-organic-product-consumer-preference adresinden erişildi.

Kline, R. B. (2005). Structural Equation Modeling. Newyork: The Guilford Press.

Lea, E., \& Wosley, T. (2005). Australians organic food beliefs, demographics and values. British Food Journal, 107(11), 855- 869 .

Lin, J., Lobo, A., \& Leckie, C. (2017). The role of benefits and transparency in shaping consumers' green perceived value, self-brand connection and brand loyalty. Journal of Retailing Consumer Services, 35, 133-141.

Magnusson, M., Arvola A., Hursti, U., \& Aberg L. (2001). Attitudes towards organic foods among Swedish consumers. British Food Journal, 103 (3), 209-227.

Merdan, K. (2018). Organik ürün tüketimine etki eden faktörler: Tüketicilerin tutumlarının gümüşhane ölçeğinde belirlenmesi. International Journal of Disciplines Economic and Administrative Sciences Studies, (4/8), 174-188.

Monroe, K. (1990). Pricing: Making Profitable Decisions. Second Edition. New York: McGraw- Hill.

Niessen, J., \& Hamm, U. (2008) Identifying the gap between stated and actual buying behaviour on organic products based on consumer panel data. 2nd Conference of the International Society of Organic Agriculture Research ISOFAR, Modena, Italy, June 18-20.

Nunnally, J. C. (1978). Psychometric Theory. 2 d ed. New York: McGraw-Hill.

Nguyen P. D, Nguyen V. T., \& Vo T. (2019). Key determinants of repurchase intention toward organic cosmetics. Journal of Asian Finance, Economics and Business, 6(3), 205-214.

Onurlubaş E., \& Öztürk D. (2015). Factors that affect organic product preferences and consumer attitudes. Turkish Studies International Periodical for the Languages, Literature and History of Turkish, (10/14), 557-578.

Onyango, B. M., Hallman, W. K., \& Bellows, A. C. (2007). Purchasing organic food in US food systems: A study of attitudes and practice. British Food Journal, 109(5), 399-411.

Organic Trade Association- OTA (2013). U.S. families' beliefs and attitudes study. 5 Eylül 2020 tarihinde https://ota.com/resources/consumer-attitudes-and-beliefs-study adresinden erişildi.

Özdamar, K. (2003). Modern Bilimsel Araştırma Yöntemleri. Eskişehir: Kaan Kitabevi.

Özden, S., Saygıll, M., \& Sütütemiz N. (2019). Kozmetik ürünlerin tüketiminde sağl1k bilincinin rolü. 11. IBANESS Kongresi, 9-10 Mart 2019, Türkiye, Tekirdağ, 791-802.

Özgen, P., \& Yeşiloğlu, H. (2015). Organik gıda müşterilerinin tüketim davranışlarının yaşam tarzı değişkeni çerçevesinde incelenmesi. Gazi Üniversitesi İktisadi ve İdari Bilimler Dergisi, 17 (2), 197-215.

Pearson, D., Henryks, J., \& Moffitt, L. (2007). What do buyers really want when they purchase organic foods? An investigation using product attributes. Journal of Organic Systems, 2 (1), 1-9.

Prothero \& McDonagh (1992). Producing environmentally acceptable cosmetics? The impact of environmentalism on the United Kingdom cosmetics and toiletries industry. Journal of Marketing Management 8(2), 147-166.

Punch, K. (2005). Sosyal Araştırmalara Giriş: Nicel ve Nitel Yaklaşımlar. 1. Baskl. Ankara: Siyasal Yayınevi.

Rimal, P., Arbindra., Moon, W., \& Balasubramanian, S. (2005). Agro-biotechnology and organic food purchase in the United Kingdom. British Food Journal, 107(2), 84-97.

Robinson, J. P., Shaver, P. R., \& Wrightsman, L. S. (Eds.) (1991). Measures of social psychological attitudes, Vol. 1.Measures of personality and social psychological attitudes. Academic Press. 
Sabanoğlu, T. (2020). Shampoo manufacture: sales value in the United Kingdom 2010-2019. 15 Mayıs 2020 tarihinde https://www.statista.com/statistics/331780/shampoos-sales-value-in-the-united-kingdom-uk/ (Erişim adresinden erişildi.

Salter, E. (2005). World Wildlife Conservation Association. 20 Mayı 2020 tarihinde https://www.worldwildlife.org/initiatives/wildlife-conservation adresinden erişildi.

Sarıkaya, N. (2007). Organik ürün tüketimini etkileyen faktörler ve tutumlar üzerine bir saha çalışması. Kocaeli Üniversitesi Sosyal Bilimler Enstitüsü Dergisi, 14(7), 110-125.

Santos, B., Correa, M., \& Chorilli, M. (2015). Sustainability, natural and organic cosmetics: Consumer, products, efficacy, toxicology and regulatory considerations. Brazilian Journal of Pharmaceutical Science, 51(1), 17-26.

Scott, L., \& Vigar-Ellis, D., (2014). Consumer understanding, perceptions and behaviours with regard to environmentally friendly packaging in a developing nation. International Journal of Consumer Studies, 38 (6), 642-649.

Shahbandeh M. (2020). Global natural and organic beauty market share 2019, by product. 12 Mayis 2020 tarihinde https://www.statista.com/statistics/802431/natural-organic-beauty-market-share-global-by adresinden erişildi.

Shahbandeh M. (2020), U.S. household expenditure on cosmetics, perfume and bath products 2007-2018. 4 Mart 2020 tarihinde https://www.statista.com/statistics/304996/us-expenditure-on-cosmetics-perfume-and-bath-preparation/ adresinden erişildi.

Süer, İ. (2014). Pazarlama Illkeleri. Ankara: Nobel Akademik Yayıncılık.

Storstad, O., \& Bjorkhaug, H. (2003). Foundadions of production and consumption of organic food in Norway: Common attitutes among farmers and consumers. Agriculture And Human Values, 20, 151- 163.

Tavşancıl, E. (2005). Tutumların ölçülmesi ve SPSS ile veri analizi, Ankara: Nobel Yayıncılık.

Tek, Ö. B (1999). Pazarlama ilkeleri-Global yönetimsel yaklaşım, Türkiye uygulamaları. İstanbul: Beta Yayınları.

Turjusen, H., Lieblein G., Wandel, M., \& Francis, C. (2001). Food system orentation and quality perception among consumers and producer of organik food in Hedmark Country. Food Quality And Prefences, 12, 207- 216.

Thompson, P. (1993). Quantitative reasoning, complexity and additive structures. Educational Studies in Mathematics, 25(3), 165-208.

Wier, M., Calverley, C. (2002). Market potential for organic foods in Europe. British Food Journal, 104, 45-62.

Wier, M., Jensen, O. K., Andersen, L. M., \& Millock, K. (2008). The character of demand in mature organic food markets: Great Britain and Denmark compared. Food Policy Journal, 33 (5), 406- 421.

Yiridoe, E., Ankomah, S., \& Martin, R. (2005). Comparison of Consumer Perceptions and Preference Toward Organic Versus Conventionally Produced Foods: A Review and Update of the Literature. Renewable Agriculture and Food Systems, 20 (04), 193 - 205.

Zanoli, R., \& Naspetti, S. (2002). Consumer motivations in the purchase of organic food: a means-end approach. British Food Journal, 104(8), 643- 653. 